Research Article

\title{
DENTAL SUPPLIER SELECTION WITH TOPSIS METHOD BY USING LP METHODOLOGY
}

\author{
Babek ERDEBILLLI (B.D ROUYENDEGH)* i ilknur GÜNEŞLİ, Seda ŞAHİN
}

Ankara Yıldırım Beyazıt University, Engineering and Natural Sciences Faculty, Department of Industrial Engineering, Ankara, Turkey

\begin{tabular}{l}
\hline Keywords \\
\hline Intuitionistic Fuzzy Set, \\
Linear Programming \\
(LP) Methodology \\
Supplier Selection, \\
TOPSIS Method, \\
Intuitionistic Fuzzy \\
Weighted Average (IFWA).
\end{tabular}

\begin{abstract}
Dental supplier selection is a process that allows companies to choose their suppliers correctly in the light of evaluations. Choosing the right dental suppliers is an important factor both for the efficiency of dental treatment and handling an impressive supply chain. Dental supplier selection is a multi-criterion group decision-making (MCDM) problem that contains many different criterion about the decision-makers generally ambiguous information. TOPSIS method integrated intuitionistic fuzzy set is used in this study. Real-life problems include many unpredictability and defects. Experts are involved in assigning the weights of the criterion in this study. Linear programming (LP) methodology has applied for the ranking of these weights of criterion. Then, the LP methodology is carried out and it was ensured that the appropriate orthodontic bracket suppliers were selected. This is a specific multi-criterion decision making problem. The study was followed together with the sensitivity analyses of the results. At the end of the study, it is foreseen that with the right selection of suppliers, The competitive power of companies in the market and end user satisfaction will increase.
\end{abstract}

\section{TOPSISS YÖNTEMİ İLE ORTODONTIK TEDARİKÇI SEÇIMİ}

\begin{tabular}{l}
\hline Anahtar Kelimeler \\
\hline Sezgisel Bulanık Küme, \\
Doğrusal Programlama \\
(LP) Metodolojisi, \\
Tedarikçi Seçimi, \\
TOPSIS Yöntemi, \\
Sezgisel Bulanık \\
Ağırlıklı Ortalama (IFWA).
\end{tabular}

Öz

Ortodontik Tedarikçi seçimi, firmaların ve şirketlerin tedarikçilerini değerlendirmeler ışığında daha doğru ve daha isabetli seçmelerini sağlayan bir süreçtir. Günümüzde Uygun Ortodontik sarf malzemesi tedarikçilerini seçmek, hem diş tedavisinin verimliliği hem de etkileyici bir tedarik zincirinin ele alınması için önemli bir faktördür. Ortodontik Tedarikçi seçimi, karar vericiler için genellikle birçok farklı kriter içeren çok kriterli grup karar verme (ÇKKV) problem olarak ele alınmaktadır. Bu çalışmada ÇKKV yöntemlerinde olan TOPSIS yöntemi ile bütünleştirilmiş sezgisel bulanık küme (BSBK) kullanılmıştır. Gerçek hayat problemleri birçok öngörülemezliği, karmaşıklığı ve kusuru içermektedir. Gerçekleştirilen çalışmada kriterin ağırlıklarının belirlenmesinde uzman görüşlerine yer verilmiştir. Daha sonra bu kriter ağırlıklarının sıralanması için ayrıca doğrusal programlama (DP) metodolojisi uygulanmış ve bu kapsamda uygun ortodontik braket tedarikçilerinin seçilmesi sağlanmıştır. Ele alınan konu, belirli birçok kriterli karar verme problemidir. Çalışma, sonuçları duyarlılık analizleri ile incelenmiştir. Makalenin sonunda, doğru Ortodontik Tedarikçi seçimi ile piyasada var olan şirket ve firmaların pazardaki rekabet gücünün ve son kullanıcı memnuniyetinin artacağı öngörülmektedir.

\footnotetext{
Alıntı / Cite Journal of Engineering Sciences and Design, 9(3), 940-951.

*ilgili yazar / Corresponding author: berdebilli@ybu.edu.tr, +90-0312- 906- 2234
}

Erdebilli, B., Güneşli, İ., Şahin, S., (2021). Dental Supplier Selection With TOPSíS Method By Using LP Methodology, 
Yazar Kimliği / Author ID (ORCID Number)

Babek ERDEBÍLLİ 0000-0001-8860-3903

İlknur GÜNEŞLİ, 0000-0003-3069-2565

Seda ŞAHIN, 0000-0003-0924-643X
Makale Süreci / Article Process

Başvuru Tarihi / Submission Date 31.10 .2020

Revizyon Tarihi / Revision Date

Kabul Tarihi / Accepted Date

Yayım Tarihi / Published Date
01.04 .2021

27.06.2021

21.09.2021

\section{Introduction}

Uncertainty is an issue that people face in many areas of decision making. It is important to create mathematical models used for uncertain situations in decision making. Though it could be the chance to get much information, it is still hard to cope with the uncertainty. Generally, substantial data sets comprise uncertain information. There are lots of vagueness in supply chain like many other different areas such as risk management, applications which are in the field of engineering, etc. The mathematical models are building to decrease the uncertainty. It could be harsh to deal with vagueness, although there is ample information in some cases. Data sets, which include substantial uncertain information, demonstrate an academic challenge. In ( Zadeh, 1965) introduced the notion of fuzzy sets to exhibit subjective vagueness and uncertainty (Sindhu et al., 2019). Fuzzy sets have created to deal with the vagueness or ambiguity directly. Thus, they have used for the cases which include complex situations. For example, in (Atanassov, 1994) indicated different estimable operations about these situations. Supply Chain Management is important in all areas of the industry. It is essential for the academia that aims decrease potential risks in the supply chain to increase customer satisfaction. In today's globalized world, the purchasing function has also become an essential matter since technology is changing. 23 essential evaluation criterion are described for supplier selection by Dickson (Dickson, 1966). These are considered important studies on supplier selection. In 1991, also researched supplier selection problem by Weber et. al. (1991). In 2016, presented a fuzzy approach for selecting a calibration supplier by Erginel and Gecer (2016). In 2017, Kaya's study is to provide a practical decision support tool for supplier selection decision analysis in automotive industry (Kaya, 2017). Jain et al., (2020) provide a new supplier selection framework by integrating Fuzzy Inference System and MCDM. The proposed methods for supplier selection is demonstrated in Table 1. Some of these methods do not include complex and unstructured nature. Literature summary is demonstrated in terms of the criterion in Table 2.

Table 1. The Systematic Analysis for Supplier Selection Methods

\begin{tabular}{lll}
\hline Author(s) & Proposed Method(s) & Year \\
\hline 1. Ed Timmerman & Weighted point method & 1986 \\
\hline 2. Robert E. Gregory & Matrix approach & 1986 \\
\hline 3. William R. Soukup & Vendor performance matrix approach & 1987 \\
\hline 4. Kenneth N. Thompson & Vendor profile analysis (VPA) & 1990 \\
\hline 5. Robert L. Nydick and Ronald Paul Hill & Analytic hierarchy process (AHP) & 1992 \\
\hline 6. Amir A. Sadrian, Yong S. Yoon & Mathematical programming & 1993 \\
\hline 7. C.C. Li, Y.P. Fun \& J.S. Hung & The application of FST & 1997 \\
\hline 8. Chang-Xue (Jack) Feng, Jin Wangb, Jin-Song Wangc & Multiple objective programming (MOP) & 2001 \\
\hline 9. Joseph Sarkis and Srinivas Talluri & Analytic network process (ANP) & 2002 \\
\hline 10. Chen-Tung Chena, Ching-Torng Lin, Sue-Fn Huang & Extended the concept of TOPSIS method & 2006 \\
\hline 11. Shuo-Yan Chou, Yao-Hui Chang & Strategy-aligned fuzzy simple multi-attribute & 2008 \\
\hline 12. Semih Önüt, Selin Soner Kara, Elif Işlk & rating technique (SMART) approach & supplier \\
\hline 13. Selin Soner Kara & ANP and TOPSIS methods for & 2009 \\
\hline 14. Ahmad Dargi al. & selection. & 2011 \\
\hline 15. Babak Daneshvar Rouyendegh (Babek Erdebilli) & Fuzzy TOPSIS method & 2014 \\
\hline 16. Xiao-Yue You al. & Fuzzy TOPSIS method & 2014 \\
\hline 17. Masoud Galankashi & VIKOR method & 2015 \\
\hline 18. Nihal Erginel & Fuzzy AHP approach & 2016 \\
\hline 19. Sanjay Kumar & Fuzzy approach & 2016 \\
\hline 21. Rukiye Kaya al. & Fuzzy TOPSIS method & 2018 \\
\hline 20. Naveen Jain & DEMATEL & 2017 \\
\hline 22. Sidong Xian & Fuzzy inference system & 2020 \\
\hline & Interval probability hesitant fuzzy linguistic & 2020 \\
\hline & TOPSIS method & \\
\hline
\end{tabular}


Table 2. Literature Review Summary

\begin{tabular}{|c|c|c|c|c|c|c|}
\hline Author(s) & Methodology & Year & Quality & Cost & Performance & Service \\
\hline 1. Ed Timmerman & Weighted point method & 1986 & $\bar{\checkmark}$ & $\checkmark$ & & $\checkmark$ \\
\hline 2. Robert E. Gregory & Matrix approach & 1986 & $\checkmark$ & $\checkmark$ & & \\
\hline 3. William R. Soukup & Vendor performance matrix approach & 1987 & & $\checkmark$ & $\checkmark$ & \\
\hline 4. Kenneth N. Thompson & Vendor profile analysis (VPA) & 1990 & & $\checkmark$ & $\checkmark$ & $\checkmark$ \\
\hline $\begin{array}{l}\text { 5. Robert L. Nydick and Ronald } \\
\text { Paul Hill }\end{array}$ & Analytic hierarchy process (AHP) & 1992 & $\checkmark$ & $\checkmark$ & & $\checkmark$ \\
\hline 6. Amir A. Sadrian, Yong S. Yoon & Mathematical programming & 1993 & $\checkmark$ & $\checkmark$ & $\checkmark$ & \\
\hline 7. C.C. Li, Y.P. Fun \& J.S. Hung & The application of FST & 1997 & $\checkmark$ & $\checkmark$ & $\checkmark$ & \\
\hline $\begin{array}{l}\text { 8. Chang-Xue (Jack) Feng, Jin } \\
\text { Wangb, Jin-Song Wangc }\end{array}$ & Multiple objective programming (MOP) & 2001 & $\checkmark$ & $\checkmark$ & $\checkmark$ & \\
\hline $\begin{array}{l}\text { 9. Joseph Sarkis and Srinivas } \\
\text { Talluri }\end{array}$ & Analytic network process (ANP) & 2002 & $\checkmark$ & $\checkmark$ & $\checkmark$ & $\checkmark$ \\
\hline $\begin{array}{l}\text { 10. Chen-Tung Chena, Ching-Torng } \\
\text { Lin, Sue-Fn Huang }\end{array}$ & Extended the concept of TOPSIS methodzx & 2006 & $\checkmark$ & $\checkmark$ & $\checkmark$ & $\checkmark$ \\
\hline 11. Shuo-Yan Chou, Yao-Hui Chang & $\begin{array}{l}\text { Strategy-aligned fuzzy simple multi-attribute rating technique } \\
\text { (SMART) approach }\end{array}$ & 2008 & $\checkmark$ & $\checkmark$ & $\checkmark$ & $\checkmark$ \\
\hline $\begin{array}{l}\text { 12. Semih Önüt, Selin Soner Kara, } \\
\text { Elif Işık }\end{array}$ & ANP and TOPSIS methods for supplier selection. & 2009 & $\checkmark$ & $\checkmark$ & $\checkmark$ & $\checkmark$ \\
\hline 13. Selin Soner Kara & Fuzzy TOPSIS method & 2011 & $\checkmark$ & $\checkmark$ & $\checkmark$ & $\checkmark$ \\
\hline 14. Ahmad Dargi al. & A Fuzzy-ANP method & 2014 & $\checkmark$ & $\checkmark$ & $\checkmark$ & $\checkmark$ \\
\hline $\begin{array}{l}\text { 15. Babak Daneshvar Rouyendegh } \\
\text { (Babek Erdebilli) }\end{array}$ & Fuzzy TOPSIS method & 2014 & $\checkmark$ & $\checkmark$ & $\checkmark$ & $\checkmark$ \\
\hline 16. Xiao-Yue You al. & VIKOR method & 2015 & $\checkmark$ & $\checkmark$ & & $\checkmark$ \\
\hline 17. Masoud Galankashi & Fuzzy AHP approach & 2016 & $\checkmark$ & $\checkmark$ & $\checkmark$ & \\
\hline 18. Nihal Erginel & Fuzzy approach & 2016 & $\checkmark$ & $\checkmark$ & $\checkmark$ & $\checkmark$ \\
\hline 19. Rukiye Kaya al. & DEMATEL & 2017 & $\checkmark$ & $\checkmark$ & $\checkmark$ & $\checkmark$ \\
\hline 20. Sanjay Kumar & Fuzzy TOPSIS method & 2018 & $\checkmark$ & $\checkmark$ & $\checkmark$ & $\checkmark$ \\
\hline 21. Naveen Jain & Fuzzy inference system & 2020 & $\checkmark$ & $\checkmark$ & $\checkmark$ & $\checkmark$ \\
\hline 22. Sidong Xian, Hailin Guo & Interval probability hesitant fuzzy linguistic TOPSIS method & 2020 & & $\checkmark$ & $\checkmark$ & \\
\hline
\end{tabular}


In supply chain management include many purchasing activities. The activities are also associated with vendor standards and uncertain. All these activities are prominent for criterion and alternatives. Intuitionistic fuzzy sets are used to overcome vagueness obstacles. The TOPSIS method taking into account both positive-ideal and negative-ideal solutions. So, the TOPSIS method integrated with the intuitionistic fuzzy set has a significant opportunity for achievement for the supplier selection process. The importance of criterion and the impact of alternatives on the criterion provided by decision makers are difficult to express with clear data in the selection of the supplier problem (Boran et al., 2009). In supplier selection process, combining intuitionistic fuzzy set gives the chance of success.

Evaluating of different dental suppliers is essential since experts linguistically indicated their thoughts on dental products. An intuitionistic fuzzy set is characterized by a membership function, non-membership function, and hesitation margin (Boran, 2011). Thus, it is an effective method. This study recommends an intuitionistic fuzzy multi-criterion group decision making with the TOPSIS method on account of correct supplier selection. The weights of the criterion that are given by the experts are precisely obscure. We have utilized the LP technique to reach the total weights of criterion under some constraints. After that, we used these weights of criterion to understand the best choice from the dedicated alternatives.

\section{Intuitionistic Fuzzy Sets}

The intuitionistic fuzzy set is presented by Atanassov (1986). This method is very suitable for uncertainty situations. Intuitionistic fuzzy set A written as follows:

$A=\left\{x, \mu_{A}(x), v_{A}(x)>\mid x \in X\right\}$

where $\mu_{A}(x), v_{A}(x): X \rightarrow[0,1]$ are membership function and nonmembership function, in order, so;

$$
0 \leq \mu_{A}(x)+v_{A}(x) \leq 1
$$

The third parameter of IFS $\pi_{A}(x)$, is given as the intuitionistic fuzzy index or hesitation degree of whether $\mathrm{x}$ belongs to A or not.

$$
\pi_{A}=1-\mu_{A}(x)-v_{A}(x)
$$

It is evidently seen that for every $x \in X$ :

$$
0 \leq \pi_{A}(x) \leq 1
$$

The precision of $\mathrm{x}$ is directly proportional to the smallness of $\pi_{A}(x)$. When $\mu_{A}(x)=1-v_{A}(x)$ for all elements of the universe, the ordinary fuzzy set concept is recovered.

Let A and B are IFSs of the set X; then multiplication operator is given as follows (Atanassov, 1986):

$$
A \otimes B=\left\{\mu_{A}(x) \cdot \mu_{B}(x), v_{A}(x)+v_{B}(x)-v_{A}(x) \cdot v_{B}(x) \mid x \in X\right\}
$$

\section{Intuitionistic Fuzzy TOPSIS}

Let $A=\left\{A_{1}, A_{2}, \ldots, A_{m}\right\}$ be a series of alternatives and $X=\left\{X_{1}, X_{2}, \ldots, X_{n}\right\}$ be a series of criterion, the procedure seeing Intuitionistic Fuzzy TOPSIS method is defined as follows:

Step 1. The following procedure is known as Chen and Huang's MCDM method for determination of the weight of decision makers:

Imagine that a decision group includes three decision-makers;

$D^{\sim}=\left(d_{i j}^{\sim}\right)_{m x n}=\left(\left[a_{i j}{ }^{-}, a_{i j}{ }^{+}\right],\left[b_{i j}{ }^{-}, b_{i j}{ }^{+}\right]\right)$, calculate the score value $m_{i j}$ of the evaluating IVIFV(Interval-Valued Intuitionistic Fuzzy Values $) \mathrm{d}_{i j}^{\sim}$ to construct the transformed decision matrix $\mathrm{M}=\left(m_{i j}\right)_{m x n}$, where

$$
m_{i j}=\frac{a_{i j}{ }^{-}-b_{i j}{ }^{-}+a_{i j}{ }^{+}-b_{i j}{ }^{+}}{2} \quad m_{i j} \in[-1,1]
$$


According to Eq. 5 establish the following LP model to maximize the objective function $S$ (Score function):

$$
\text { Maximize } S=\sum_{i=1}^{m} \sum_{j=1}^{n} w_{j} x m_{i j},
$$

where $w_{j}$ is the optimal weight of decision-makers.

Step 2. Creating an intuitionistic fuzzy decision matrix. Let $R^{k}=\left(r_{i j}^{(k)}\right)_{m x n}$ is an intuitionistic fuzzy decision matrix of each decision-maker. $\lambda=\left\{\lambda_{1}, \lambda_{2}, \lambda_{3}, \ldots, \lambda_{l}\right.$ is the weight of each decision-maker and $\sum_{k=1}^{1} \lambda_{k}=1, \lambda_{k} \in[0,1]$. IFWA (Intuitionistic Fuzzy Weighted Average) operator referred by Xu (2007) is used. $R=\left(r_{i j}\right)_{m x n^{\prime}}$, where

$$
\begin{aligned}
& r_{i j}=I F W A_{\lambda}\left(r_{i j}^{(1)}, r_{i j}^{(2)} \ldots, r_{i j}^{(l)}\right) \\
& =\lambda_{1} r_{i j}^{(1)} \oplus \lambda_{2} r_{i j}^{(2)} \oplus \lambda_{3} r_{i j}^{(3)} \oplus \ldots \oplus \lambda_{l} r_{i j}^{(l)} \\
& =\left[1-\prod_{k=1}^{l}\left(1-\mu_{i j}^{(k)}\right)^{\lambda_{k}}, \prod_{k=1}^{l}\left(v_{i j}^{(k)}\right)^{\lambda_{k}}, \prod_{k=1}^{l}\left(1-\mu_{i j}^{(k)}\right)^{\lambda_{k}}-\prod_{k=1}^{l}\left(v_{i j}^{(k)}\right)^{\lambda_{k}}\right]
\end{aligned}
$$

Here $r_{i j}=\left(\mu_{A_{i}}\left(x_{j}\right), v_{A_{i}}\left(x_{j}\right), \pi_{A_{i}}\left(x_{j}\right)\right)(i=1,2,3, \ldots, m ; j=1,2, \ldots, n)$.

R matrix is obtained:

$$
R=\left[\begin{array}{ccccc}
r_{11} & r_{12} & r_{13} & & r_{1 m} \\
r_{21} & r_{22} & r_{23} & \cdots & r_{2 m} \\
& \vdots & & \ddots & \vdots \\
r_{n 1} & r_{n 2} & r_{n 3} & \cdots & r_{n m}
\end{array}\right]
$$

Step 3. Determination of the weights of the criterion. W symbolizes a set of grades of importance. In order to achieve $\mathrm{W}$, all the individual decision-maker opinions for the importance of each criterion need to be combined (Biderci and Canbaz, 2019).

Let $w_{j}=\left[\mu_{k}{ }^{(k)}, v_{k}{ }^{(k)}, \pi_{k}{ }^{(k)}\right]$ be an intuitionistic fuzzy number operated to criterion $X j$ by the kth decision-maker.

$$
\begin{aligned}
& w_{j}=I F W A_{\lambda}\left(w_{j}^{(1)}, w_{j}^{(2)} \ldots, w_{j}^{(l)}\right) \\
& =\lambda_{1} w_{j}^{(1)} \oplus \lambda_{2} w_{j}^{(2)} \oplus \lambda_{3} w_{j}^{(3)} \oplus \ldots \oplus \lambda_{l} w_{j}^{(l)} \\
& =\left[1-\prod_{k=1}^{l}\left(1-\mu_{j}^{(k)}\right)^{\lambda_{k}}, \prod_{k=1}^{l}\left(v_{j}^{(k)}\right)^{\lambda_{k}}, \prod_{k=1}^{l}\left(1-\mu_{j}^{(k)}\right)^{\lambda_{k}}-\prod_{k=1}^{l}\left(v_{j}^{(k)}\right)^{\lambda_{k}}\right] \\
& W=\left[w_{1}, w_{2}, w_{3, \ldots,} w_{j}\right]
\end{aligned}
$$

Here $w_{j}=\left(\mu_{j}, v_{j}, \pi_{j}\right)(j=1,2, \ldots, n)$.

Step 4..The aggregated weighted intuitionistic fuzzy decision matrix is obtained.

$$
R \otimes W=\left\{\left\langle x, \mu_{A_{i}}(x) \cdot \mu_{W}(x), v_{A_{i}}(x)+v_{W}(x)-v_{A_{i}}(x) \cdot v_{W}(x)\right\rangle \mid x \in X\right\}
$$

And

$$
\pi_{A_{i}} \cdot w(x)=1-v_{A_{i}}(x)-v_{W}(x)-\mu_{A_{i}}(x) \cdot \mu_{W}(x)+v_{A_{i}}(x) \cdot v_{W}(x)
$$

$R^{\prime}$ mean is the aggregated weighted intuitionistic fuzzy decision matrix, such that: 


$$
=\left[\begin{array}{rrrr}
\left(\mu_{A_{1} W}\left(x_{1}\right), v_{A_{1} W}\left(x_{1}\right), \pi_{A_{1} W}\left(x_{1}\right)\right) & \left(\mu_{A_{1} W}\left(x_{2}\right), v_{A_{1} W}\left(x_{2}\right), \pi_{A_{1}}\left(x_{2}\right)\right) & & \left(\mu_{A_{1 W}}\left(x_{n}\right), v_{A_{1} W}\left(x_{n}\right), \pi_{A_{1} W}\left(x_{n}\right)\right) \\
\left(\mu_{A_{2} W}\left(x_{1}\right), v_{A_{2} W}\left(x_{1}\right), \pi_{A_{2} W}\left(x_{1}\right)\right) & \left(\mu_{A_{2} W}\left(x_{2}\right), v_{A_{2} W}\left(x_{2}\right), \pi_{A_{2}}\left(x_{2}\right)\right) & & \left(\mu_{A_{2 W}}\left(x_{n}\right), v_{A_{2} W}\left(x_{n}\right), \pi_{A_{2} W}\left(x_{n}\right)\right) \\
\vdots & \ddots & \vdots \\
\left(\mu_{A_{m} W}\left(x_{1}\right), v_{A_{m} W}\left(x_{1}\right), \pi_{A_{m} W}\left(x_{1}\right)\right) & \left(\mu_{A_{m} W}\left(x_{2}\right), v_{A_{m}}\left(x_{2}\right), \pi_{A_{m}}\left(x_{2}\right)\right) & \cdots & \left(\mu_{A_{m} W}\left(x_{n}\right), v_{A_{m} W}\left(x_{n}\right), \pi_{A_{m} W}\left(x_{n}\right)\right)
\end{array}\right]
$$

Table 3. Linguistic Terms Description of Separate Index Level

\begin{tabular}{cc}
\hline Linguistic Terms & ${ }^{*}$ IFNs ${ }^{\boldsymbol{a}}$ \\
\hline Very good (VG) & $(\mathbf{0 . 9 0 , 0 . 1 0 )}$ \\
\hline Good $(\mathrm{G})$ & $(\mathbf{0 . 7 5 , 0 . 2 0 )}$ \\
\hline Medium $(\mathrm{M})$ & $(\mathbf{0 . 5 0 , 0 . 4 5 )}$ \\
\hline Bad (B) & $(\mathbf{0 . 3 5 , 0 . 6 0 )}$ \\
\hline Very Bad (VB) & $(\mathbf{0 . 1 0 , 0 . 9 0 )}$
\end{tabular}

*IFN Intuitionistic fuzzy number.

$R^{\prime}=\left[\begin{array}{ccccc}r_{11}^{\prime} & r_{12}^{\prime} & r_{13}^{\prime} & \ldots & r_{1 j}^{\prime} \\ r_{21}^{\prime} & r_{22}^{\prime} & r_{23}^{\prime} & & r_{2 j}^{\prime} \\ & \vdots & & \ddots & \vdots \\ r^{\prime}{ }_{i 1} & r_{i 2} & r_{i 3}^{\prime} & \cdots & r_{i j}^{\prime}\end{array}\right]$

$r_{i j}^{\prime}=\left(\mu_{i j}^{\prime}, v^{\prime}{ }_{i j}, \pi^{\prime}{ }_{i j}\right)=\mu_{A_{i} W}\left(x_{j}\right), v_{A_{i} W}\left(x_{j}\right), \pi_{A_{i} W}\left(x_{j}\right)(j=1,2, \ldots, n)$ is an element of the aggregated weighted intuitionistic fuzzy decision matrix (Wen, et al. 2010).

Step 5. Intuitionistic fuzzy negative solution represented by $A^{*}$. Intuitionistic fuzzy positive solution represented by $A^{-}$.

Such that:

$$
\begin{aligned}
& A^{*}=\left(\mu_{A^{*} W}\left(x_{j}\right), v_{A^{*} W}\left(x_{j}\right)\right) \text { and } A^{-}=\left(\mu_{A^{-} W}\left(x_{j}\right), v_{A^{-} W}\left(x_{j}\right)\right) \\
& \mu_{A^{*} W}\left(x_{j}\right)=\left(\left(\max _{i} \mu_{A i . W}\left(x_{j}\right) \mid j \in J_{1}\right),\left(\min _{i} \mu_{A i . W}\left(x_{j}\right) j \in J_{2}\right)\right) \\
& v_{A^{*} W}\left(x_{j}\right)=\left(\left(\min _{i} v_{A i . W}\left(x_{j}\right) \mid j \in J_{1}\right),\left(\max _{i} v_{A i . W}\left(x_{j}\right) j \in J_{2}\right)\right) \\
& \mu_{A^{-} W}\left(x_{j}\right)=\left(\left(\min _{i} \mu_{A i . W}\left(x_{j}\right) \mid j \in J_{1}\right),\left(\max _{i} \mu_{A i^{*} W}\left(x_{j}\right) j \in J_{2}\right)\right) \\
& v_{A^{-} W}\left(x_{j}\right)=\left(\left(\max _{i} v_{A i . W}\left(x_{j}\right) j \in J_{1}\right),\left(\min _{i} v_{A i . W}\left(x_{j}\right) j \in J_{2}\right)\right)
\end{aligned}
$$

Step 6."Separation measures $\left(S_{i^{*}}\right.$ and $\left.S_{i^{-}}\right)$are calculated. We use normalized Euclidean distance. Then, $S_{i^{*}}$ and $S_{i^{-}}$ are obtained."

The linguistic terms in Table 3 are used for the decision makers to rate the alternatives.

$$
\begin{gathered}
S^{*}=\sqrt{\frac{1}{2 n} \sum_{j=1}^{n}\left[\left(\mu_{A i W}\left(x_{j}\right)-\mu_{A^{*} W}\left(x_{j}\right)\right)^{2}+\left(v_{A i W}\left(x_{j}\right)-v_{A^{*} W}\left(x_{j}\right)\right)^{2}+\left(\pi_{A i W}\left(x_{j}\right)-\pi_{A^{*} W}\left(x_{j}\right)\right)^{2}\right]} \\
S^{-}=\sqrt{\frac{1}{2 n} \sum_{j=1}^{n}\left[\left(\mu_{A i W}\left(x_{j}\right)-\mu_{A^{-} W}\left(x_{j}\right)\right)^{2}+\left(v_{A i W}\left(x_{j}\right)-v_{A^{-} W}\left(x_{j}\right)\right)^{2}+\left(\pi_{A i W}\left(x_{j}\right)-\pi_{A^{-} W}\left(x_{j}\right)\right)^{2}\right]}
\end{gathered}
$$

Step 7. Relative closeness coefficient is calculated the according to the intuitionistic ideal solution.

$$
C_{i^{*}}=\frac{S_{i^{-}}}{S_{i^{*}+S_{i^{-}}}} \text {where } 0 \leq C_{i^{*}} \leq 1
$$

Step 8. Ranking the alternatives in the light of other steps. Alternatives are ranked according to $C_{i^{*}}{ }^{\prime}$. 


\section{Numerical Example}

In this study, deciding the most appropriate orthodontic brackets supplier is aimed. It is a must for one of the pivot elements in its dental treatment process. Four suppliers who are called A1, A2, A3, and A4 have taken as alternatives for further evaluation. These alternative suppliers have evaluated by three orthodontists who are also called decision-makers of the study. The decision-makers have composed five criterion to evaluate alternative suppliers. These criterion are considered:

C1: Type of the brackets

C2: Size of the brackets

C3: Shape of the brackets

C4: Durability of the brackets

C5: Usability of the brackets

The following steps have demonstrated the procedure of intuitionistic fuzzy TOPSIS method for orthodontic brackets supplier, which are briefly explained in Section 2 and Section 3:

Step 1. Determining the weights of the decision-makers.

Table 4 demonstrates the importance of the degree of the decision-makers on the group. A linear programming model is constructed to handle the weights of the decision-makers' opinions, as follows:

Maximize $S=\sum_{i=1}^{3} \sum_{j=1}^{3} w_{j} x m_{i j}$ where $w_{1}\left(D M_{1}\right), w_{2}\left(D M_{2}\right)$ and $w_{3}\left(D M_{3}\right)$ are the optimal weights of the decisionmakers.

$0.20 \leq w_{1} \leq 0.70$

$0.30 \leq w_{2} \leq 0.55$

$0.30 \leq w_{3} \leq 0.45$

$w_{1}+w_{2}+w_{3}=1$

We can get the optimal weights $w_{1}=0.30, w_{2}=0.50$, and $w_{3}=0.20$.

Table 4. The Importance of Decision-Makers And Their Weights

\begin{tabular}{|c|c|c|c|}
\hline & $D M_{1}$ & $D M_{2}$ & $D M_{3}$ \\
\hline Linguistic Terms & Very Good & Medium & Good \\
\hline Weight & 0.30 & 0.50 & 0.20 \\
\hline
\end{tabular}

Table 5. Linguistic Terms For Rating The Importance of Criterion And The Decision-Makers

\begin{tabular}{|c|c|}
\hline Linguistic Terms & $\mathrm{IFN}^{\boldsymbol{s}^{\alpha}}$ \\
\hline Very good & $(0.90,0.10)$ \\
\hline Good & $(0.75,0.20)$ \\
\hline Medium & $(0.50,0.45)$ \\
\hline Bad & $(0.35,0.60)$ \\
\hline Very bad & $(0.10,0.90)$ \\
\hline
\end{tabular}

Step 2. Constructing the aggregated intuitionistic fuzzy decision matrix based on the opinions of decision-makers.

Table 6. Linguistic Terms For Rating The Alternatives

\begin{tabular}{|c|c|}
\hline Linguistic Terms & IFN $^{\boldsymbol{s}}$ \\
\hline Very good (VG) & $(0.75,0.10,0.15)$ \\
\hline Good (G) & $(0.60,0.25,0.15)$ \\
\hline Medium (M) & $(0.50,0.50,0.00)$ \\
\hline Bad (B) & $(0.25,0.60,0.15)$ \\
\hline Very Bad (VB) & $(0.10,0.75,0.15)$ \\
\hline
\end{tabular}


Table 7. The Ratings of The Alternatives

\begin{tabular}{|c|c|c|c|c|c|c|}
\hline \multirow{2}{*}{ Decision Makers } & & \multicolumn{5}{|c|}{ Criterion } \\
\hline$D M_{1}$ & Alternatives & $C_{1}$ & $C_{2}$ & $C_{3}$ & $C_{4}$ & $C_{5}$ \\
\hline & $\mathrm{A} 1$ & $\mathrm{~B}$ & $\mathrm{G}$ & $\mathrm{M}$ & $\mathrm{G}$ & $\mathrm{M}$ \\
\hline & $\mathrm{A} 2$ & $\mathrm{G}$ & $\mathrm{VB}$ & $\mathrm{G}$ & $\mathrm{G}$ & $\mathrm{VB}$ \\
\hline & $\mathrm{A} 3$ & $\mathrm{VG}$ & $\mathrm{VG}$ & $\mathrm{M}$ & $\mathrm{M}$ & $\mathrm{VG}$ \\
\hline$D M_{2}$ & $\mathrm{~A} 4$ & $\mathrm{~B}$ & $\mathrm{M}$ & $\mathrm{G}$ & $\mathrm{M}$ & $\mathrm{G}$ \\
\hline & $\mathrm{A} 1$ & $\mathrm{~B}$ & $\mathrm{M}$ & $\mathrm{M}$ & $\mathrm{M}$ & $\mathrm{G}$ \\
\hline & $\mathrm{A} 2$ & $\mathrm{G}$ & $\mathrm{B}$ & $\mathrm{M}$ & $\mathrm{G}$ & $\mathrm{VB}$ \\
\hline & $\mathrm{A} 3$ & $\mathrm{VG}$ & $\mathrm{VG}$ & $\mathrm{M}$ & $\mathrm{VG}$ & $\mathrm{M}$ \\
\hline$D M_{3}$ & $\mathrm{~A} 4$ & $\mathrm{~B}$ & $\mathrm{M}$ & $\mathrm{G}$ & $\mathrm{G}$ & $\mathrm{G}$ \\
\hline & $\mathrm{A} 1$ & $\mathrm{G}$ & $\mathrm{B}$ & $\mathrm{M}$ & $\mathrm{M}$ & $\mathrm{M}$ \\
\hline & $\mathrm{A} 2$ & $\mathrm{VG}$ & $\mathrm{VG}$ & $\mathrm{M}$ & $\mathrm{G}$ & $\mathrm{VG}$ \\
\hline & $\mathrm{A} 3$ & $\mathrm{G}$ & $\mathrm{M}$ & $\mathrm{B}$ & $\mathrm{G}$ & $\mathrm{VB}$ \\
\hline & $\mathrm{A} 4$ & $\mathrm{~B}$ & $\mathrm{M}$ & $\mathrm{G}$ & $\mathrm{G}$ & $\mathrm{G}$ \\
\hline
\end{tabular}

Table 8. The Importance Weight of The Criterion

\begin{tabular}{|l|c|c|c|}
\hline & \multicolumn{3}{|c|}{ Decision Maker } \\
\hline Criterion & $D C_{1}$ & $D C_{2}$ & $D C_{3}$ \\
\hline$C_{1}$ & $\mathrm{I}$ & $\mathrm{I}$ & $\mathrm{UI}$ \\
\hline$C_{2}$ & $\mathrm{M}$ & $\mathrm{VI}$ & $\mathrm{I}$ \\
\hline$C_{3}$ & $\mathrm{VI}$ & $\mathrm{I}$ & $\mathrm{M}$ \\
\hline$C_{4}$ & $\mathrm{UI}$ & $\mathrm{M}$ & $\mathrm{VI}$ \\
\hline$C_{5}$ & $\mathrm{I}$ & $\mathrm{M}$ & $\mathrm{M}$ \\
\hline
\end{tabular}

The ratings for the following five criterion are taken by the decision-makers. These are shown in Table 9. The aggregated intuitionistic fuzzy decision matrix is created. These are based on the aggregation of decision-makers' opinions as follows in Table 9:

Table 9. The Aggregated Intuitionistic Fuzzy Decision Matrix (R)

\begin{tabular}{|c|c|c|c|c|c|}
\hline & $C_{1}$ & $C_{2}$ & $C_{3}$ & $C_{4}$ & $C_{5}$ \\
\hline & {$[0.339,0.504$,} & {$[0.493,0.421$,} & {$[0.500,0.500$,} & {$[0.532,0.406$,} & {$[0.553,0.354$,} \\
$A_{1}$ & $0.158]$ & $0.086]$ & $0.000]$ & $0.061]$ & $0.094]$ \\
\hline & {$[0.636,0.208$,} & {$[0.364,0.448$,} & {$[0.532,0.406$,} & {$[0.600,0.250$,} & {$[0.303,0.501$,} \\
$A_{2}$ & $0.156]$ & $0.188]$ & $0.061]$ & $0.150]$ & $0.195]$ \\
\hline & {$[0.725,0.120$,} & {$[0.713,0.138$,} & {$[0.458,0.519$,} & {$[0.662,0.195$,} & {$[0.543,0.335$,} \\
$A_{3}$ & $0.155]$ & $0.149]$ & $0.024]$ & $0.143]$ & $0.122]$ \\
\hline & {$[0.250,0.600$,} & {$[0.500,0.500$,} & {$[0.600,0.250$,} & {$[0.572,0.195$,} & {$[0.600,0.250$,} \\
$A_{4}$ & $0.150]$ & $0.000]$ & $0.150]$ & $0.120]$ & $0.150]$ \\
\hline
\end{tabular}

Step 3. Determining the weights of the each criterion.

According to the equation, the importance of the criterion is created as linguistic terms are demonstrated in Table 10. The decision-makers' opinions on criterion are aggregated using Equation (7) to handle the weight of each criterion. Then, the weights of the criterion (W) are obtained by using IFWA (Intuitionistic fuzzy weighted averaging) decision-maker as below:

\section{$W=\{(0.697,0.003,0.300) ;(0.805,0.02,0.193) ;(0.782,0.05,0.214) ;$ $(0.608,0.004,0.388) ;(0.594,0.012,0.394)\}$}

Step 4. The aggregated weighted intuitionistic fuzzy decision matrix are obtained by utilizing Equation (8). Then, this matrix is determined as: 
Table 10. The Aggregated Intuitionistic Fuzzy Decision Matrix (R')

\begin{tabular}{|c|c|c|c|c|c|}
\hline & $C_{1}$ & $C_{2}$ & $C_{3}$ & $C_{4}$ & $C_{5}$ \\
\hline & {$[0.236,0.002$,} & {$[0.397,0.001$,} & {$[0.391,0.002$,} & {$[0.324,0.002$,} & {$[0.328,0.004$,} \\
$A_{1}$ & $0.047]$ & $0.017]$ & $0.000]$ & $0.024]$ & $0.037]$ \\
\hline & {$[0.443,0.001$,} & {$[0.293,0.001$,} & {$[0.416,0.002$,} & {$[0.365,0.001$,} & {$[0.180,0.006$,} \\
$A_{2}$ & $0.047]$ & $0.036]$ & $0.013]$ & $0.058]$ & $0.077]$ \\
\hline & {$[0.506,0.000$,} & {$[0.574,0.000$,} & {$[0.358,0.002$,} & {$[0.402,0.001$,} & {$[0.323,0.004$,} \\
$A_{3}$ & $0.046]$ & $0.029]$ & $0.005]$ & $0.056]$ & $0.048]$ \\
\hline & {$[0.174,0.002$,} & {$[0.403,0.001$,} & {$[0.469,0.001$,} & {$[0.348,0.001$,} & {$[0.356,0.003$,} \\
$A_{4}$ & $0.045]$ & $0.000]$ & $0.032]$ & $0.047]$ & $0.059]$ \\
\hline
\end{tabular}

Step 5. Handling $A^{*}$ and $A^{-}$.

The intuitionistic fuzzy positive-ideal and negative-ideal solutions are obtained as follows:

$r_{1}^{*}=(0.506,0.000,0.494)$

$r_{2}^{*}=(0.574,0.000,0.426)$

$r_{3}^{*}=(0.469,0.001,0.530)$

$r_{4}^{*}=(0.402,0.001,0.597)$

$r_{5}^{*}=(0.356,0.003,0.641)$

$r_{1}^{-}=(0.174,0.002,0.824)$

$r_{2}^{-}=(0.293,0.001,0.706)$

$r_{3}^{-}=(0.358,0.002,0.640)$

$r_{4}^{-}=(0.324,0.002,0.674)$

$r_{5}^{-}=(0.180,0.006,0.814)$

Step 6. Calculating the $\mathrm{S}_{\mathrm{i}}{ }^{*}$ and $\mathrm{S}_{\mathrm{i}-\text {. }}$.

Table 11 demonstrated the negative and positive separation measures based on normalized Euclidean distance for each alternative.

Table 11. Separation Measures And The Relative Closeness Coefficient of Each Alternative

\begin{tabular}{|c|c|c|c|}
\hline Alternatives & $\mathrm{S}_{\mathrm{i}}{ }^{*}$ & $\mathrm{~S}_{\mathrm{i}^{-}}$ & $\mathrm{C}_{\mathrm{i}}$ \\
\hline $\mathrm{A} 1$ & 1.332 & 1.666 & 2.917 \\
\hline $\mathrm{A} 2$ & 1.536 & 1.899 & 3.135 \\
\hline $\mathrm{A} 3$ & 1.325 & 2.157 & 3.785 \\
\hline $\mathrm{A} 4$ & 1.532 & 1.950 & 3.223 \\
\hline
\end{tabular}

Step 7. Ranking the alternatives.

The alternative with the highest affinity coefficient means the most successful alternative with the highest score, and vice versa. The relative closeness coefficients are determined, and then four alternatives are sorted according to the descending order of $C_{i}$ 's. The alternatives are ranked as $A_{3}>A_{4}>A_{2}>A_{1}$. All in all, alternative three (A3) is selected as an appropriate supplier among four alternatives.

\section{Sensitivity Analysis}

It is essential to consider if there is a change in the weights of the five main criterion. Therefore, a sensitivity analysis is performed depending on the weight of each main criterion. In the sensitivity analysis using MS Excel, the weights of the criterion are examined by changing as as $w_{1}=0.30, w_{2}=0.40$, and $w_{3}=0.30$. 
Table 12. The Aggregated Intuitionistic Fuzzy Decision Matrix (R") for $w_{1}=0.30, w_{2}=0.40$, and $w_{3}=0.30$

\begin{tabular}{|c|c|c|c|c|c|}
\hline & $\mathrm{C}_{1}$ & $\mathrm{C}_{2}$ & $\mathrm{C}_{3}$ & $\mathrm{C}_{4}$ & $\mathrm{C}_{5}$ \\
\hline & {$[0.264,0.001$,} & {$[0.380,0.001$,} & {$[0.391,0.002$,} & {$[0.324,0.002$,} & {$[0.322,0.005$,} \\
$\mathrm{A}_{1}$ & $0.048]$ & $0.019]$ & $0.000]$ & $0.024]$ & $0.031]$ \\
\hline & {$[0.445,0.001$,} & {$[0.347,0.001$,} & {$[0.416,0.002$,} & {$[0.365,0.001$,} & {$[0.230,0.005$,} \\
$\mathrm{A}_{2}$ & $0.047]$ & $0.038]$ & $0.013]$ & $0.058]$ & $0.080]$ \\
\hline & {$[0.497,0.000$,} & {$[0.557,0.000$,} & {$[0.340,0.002$,} & {$[0.392,0.001$,} & {$[0.306,0.004$,} \\
$\mathrm{A}_{3}$ & $0.047]$ & $0.028]$ & $0.008]$ & $0.055]$ & $0.054]$ \\
\hline & {$[0.174,0.002$,} & {$[0.403,0.001$,} & {$[0.469,0.001$,} & {$[0.348,0.001$,} & {$[0.356,0.003$,} \\
$\mathrm{A}_{4}$ & $0.045]$ & $0.000]$ & $0.032]$ & $0.047]$ & $0.059]$ \\
\hline
\end{tabular}

It is handled intuitionistic fuzzy positive and negative-ideal solution. The intuitionistic fuzzy positive-ideal solution and intuitionistic fuzzy negative-ideal solution are determined for the sensitivity analysis (with the weights of the criterion $w_{1}=0.30, w_{2}=0.40$, and $w_{3}=0.30$ ) as follows:

$$
\begin{aligned}
& r_{1}^{*}=(0.497,0.000,0.503) \\
& r_{2}^{*}=(0.557,0.000,0.443) \\
& r_{3}^{*}=(0.469,0.001,0.530) \\
& r_{4}^{*}=(0.392,0.001,0.607) \\
& r_{5}^{*}=(0.356,0.003,0.641) \\
& r_{1}^{-}=(0.174,0.002,0.824) \\
& r_{2}^{-}=(0.347,0.001,0.652) \\
& r_{3}^{-}=(0.340,0.002,0.658) \\
& r_{4}^{-}=(0.324,0.002,0.674) \\
& r_{5}^{-}=(0.230,0.005,0.765)
\end{aligned}
$$

Table 13 demonstrated the both negative and positive separation measures based on normalized Euclidean distance for each alternative. These are calculated for sensitivity analysis in the next chapter.

Table 13. Separation Measures And The Relative Closeness Coefficient of Each Alternative For Sensitivity Analysis

\begin{tabular}{|c|c|c|c|}
\hline Alternatives & $\mathrm{Si}^{*}$ & $\mathrm{Si}-$ & $\mathrm{C}_{\mathrm{i}}$ \\
\hline $\mathrm{A}_{1}$ & 1.332 & 1.581 & 2.768 \\
\hline $\mathrm{A}_{2}$ & 1.536 & 1.866 & 3.081 \\
\hline $\mathrm{A}_{3}$ & 1.325 & 2.062 & 3.618 \\
\hline $\mathrm{A}_{4}$ & 1.537 & 1.864 & 3.077 \\
\hline
\end{tabular}

It is obvious that the alternative with the highest affinity coefficient means the most successful alternative with the highest score, and vice versa. Finally, the alternatives were ranked as $A_{3}>A_{2}>A_{4}>A_{1}$ when the weight of each main criterion are calculated respectively as $w_{1}=0.30, w_{2}=0.40$, and $w_{3}=0.30$. According to this sensitivity analysis, there is no difference between the first and the last alternative. The second and the third alternatives are replaced after the weights of the criterion changed with 0.004 difference. After that, the weight of each main criterion are calculated respectively as $w_{1}=0.30, w_{2}=0.30$, and $w_{3}=0.40$, and the alternatives are ranked as the same with the conclusion $\left(A_{3}>A_{2}>A_{4}>A_{1}\right)$. Sensitivity analysis, according to the weight of each main criterion, is given in Figure 1. All in all, alternative three $A_{3}$ ) are selected as an appropriate supplier among four alternatives for different weights. There is a minor change when Sensitivity Analysis is done according to the weight of each main criterion. 


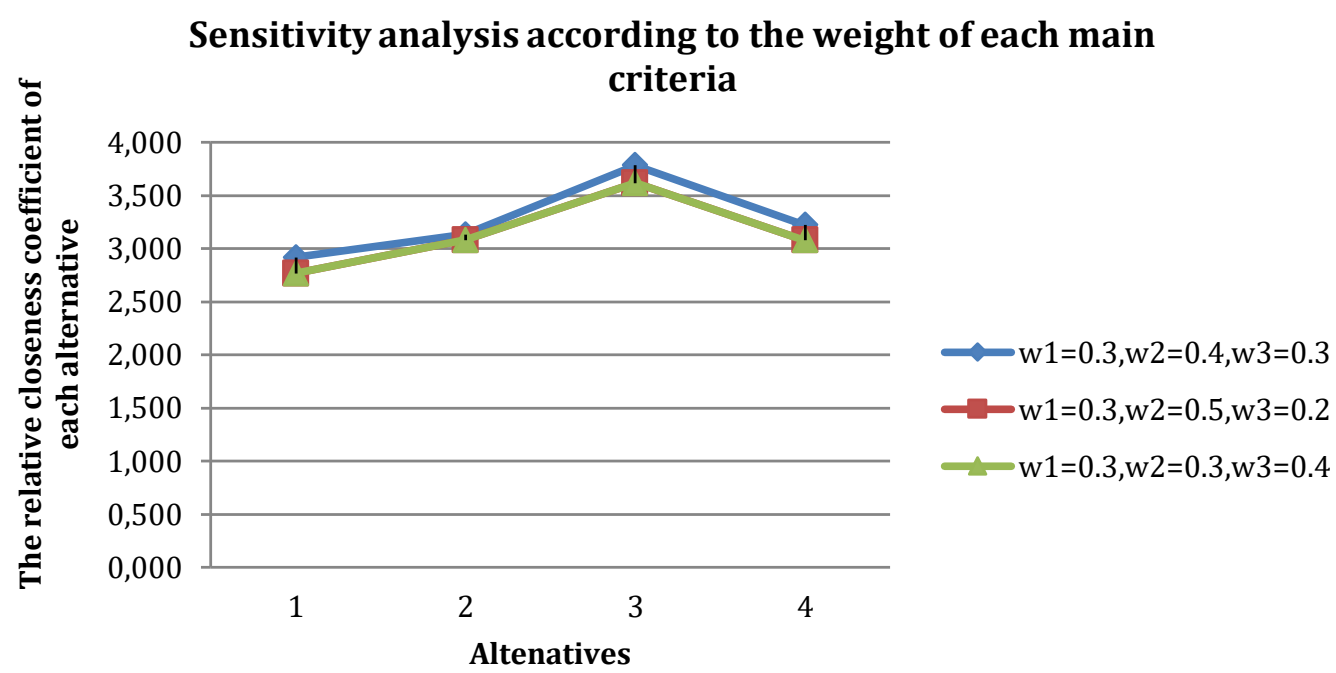

Figure 1. Sensitivity Analysis According to The Weight of Each Main Criterion

\section{Conclusion}

The purpose of this study is to analyze the orthodontic brackets suppliers according to the specified measurements and to select appropriate the best. The TOPSIS method is proposed. Group decision-making environment is used for these selection. Thus, these methods are combined for the study. Ambiguity is a common occurrence in decision making. The LP model has managed to deal with uncertainty. Uncertainty is inherent in decision-making processes, so intuitionistic fuzzy set is used by applying this method. According to the information handled from the decisionmakers, the most suitable alternative is selected among four alternatives by using the intuitive fuzzy TOPSIS method. Linear programming (LP) methodology is utilized for theeach weight of decision makers. Then, the linguistic terms are converted to intuitionistic fuzzy numbers. In order to handle intuitionistic fuzzy numbers, the ratings of each alternative concerning each criterion and the weights of each criterion are handled. Intuitionistic Fuzzy Weighted Average is mostly useful for combining heuristic fuzzy numbers. Both a heuristic fuzzy positive and negative ideal solutions are handled. All in all, the alternatives are ranked by obtaining these solutions. The methods used in this article can be expanded further and be effective in supplier selection decisions for all companies. The potential benefits from this approach can be used in making certain types of supplier selection decisions. In this way, the decisions taken are strengthened.

\section{Conflict of Interest}

No conflict of interest was declared by the authors.

\section{References}

Atanassov K. T. (1994). Operators over interval valued intuitionistic fuzzy sets. Fuzzy Sets and Systems, 64(2), 159-174. https://doi.org/10.1016/0165-0114(94)90331-X

Biderci H., Canbaz B., Ergonomic Room Selection with Intuitive Fuzzy TOPSIS Method, Procedia Computer Science, Volume 158, 2019, Pages 58-67, ISSN 1877-0509, https://doi.org/10.1016/j.procs.2019.09.153

Boran, F. E., Genç S., Kurt M., \& Akay D. (2009). A multi-criterion intuitionistic fuzzy group decision making for supplier selection with TOPSIS method. Expert Systems with Applications, 36(8), 11363-11368. https://doi.org/10.1016/j.eswa.2009.03.039

Chen C.T., Lin C.T., Huang S.F., (2006). A fuzzy approach for supplier evaluation and selection in supply chain management. Doi: 10.1016/j.ijpe.2005.03.009

Chou S. Y., Chang Y. H. (2008). A decision support system for supplier selection based on a strategy-aligned fuzzy SMART approach. Expert Systems with Applications, 34(4), 2241-2253. https://doi.org/10.1016/j.eswa.2007.03.001

Chou S.Y., Chang Y.H. (2008). A decision support system for supplier selection based on a strategy-aligned fuzzy SMART approach, Expert Systems with Applications Volume 34, Issue 4, Pages 2241-2253. https://doi.org/10.1016/j.eswa.2007.03.001

Dargi A., Anjomshoae, A., Galankashi M. R., Memari A., Tap M.B.M (2014). Supplier Selection: A Fuzzy-ANP Approach, Volume 31, 2014, Pages 691-700, Procedia Computer Science. https://doi.org/10.1016/j.procs.2014.05.317

Dickson, G. W. (1966). An Analysis of Vendor Selection Systems and Decisions. Journal of Purchasing, 2(1), 5-17. https://doi.org/10.1111/j.1745-493X.1966.tb00818.x 
Erginel N. (2016). Fuzzy multi-objective decision model for calibration supplier selection problem, Computers \& Industrial Engineering. DOI: 10.1016/j.cie.2016.10.017

Galankashi M., Helmi S. A., Hashemzahi P. (2016). Supplier selection in automobile industry: A mixed balanced scorecard-fuzzy AHP approach, Alexandria Engineering Journal Volume 55, Issue 1, March 2016, Pages 93-100. https://doi.org/10.1016/j.aej.2016.01.005

Gregory R.E., Journal of Purchasing and Materials Management, Source Selection: A Matrix Approach, 1986, https://doi.org/10.1111/j.1745-493X.1986.tb00159.x

Gulsun Nakiboglu \& Berna Bulgurcu (2021) Supplier selection in a Turkish textile company by using intuitionistic fuzzy decision-making, The Journal of The Textile Institute, 112:2, 322-332, DOI: 10.1080/00405000.2020.1747675

Haq, A. N., \& Kannan, G. (2006). Fuzzy analytical hierarchy process for evaluating and selecting a vendor in a supply chain model. International Journal of Advanced Manufacturing Technology, 29(7-8), 826-835. https://doi.org/10.1007/s00170$005-2562-8$

Jain N., (2019). Sustainable supplier selection under must-be criteria through Fuzzy inference system, Journal of Cleaner Production. DOI: 10.1016/j.jclepro.2019.119275

Kara S.S. (2011). Supplier selection with an integrated methodology in unknown environment, Expert Systems with Applications Volume 38, Issue 3, Pages 2133-2139. https://doi.org/10.1016/j.eswa.2010.07.154

Kaya R., Yet B. (2019). Building Bayesian networks based on DEMATEL for multiple criterion decision problems. Procedia Computer Science Volume 133, 2018, Pages 905-912. DOI: 10.1016/j.eswa.2019.05.053

Kumar S., Kumar S., Barman A. (2018). Supplier selection using fuzzy TOPSIS multi criteria model for a small scale steel manufacturing unit. Procedia Computer Science Volume 133, 2018, Pages 905-912. https://doi.org/10.1016/j.procs.2018.07.097

Lei W. Gao Q. (2013). Linguistic terms description of separate index level. International Journal of Environmental Protection and Policy Vol. 1, No. 4, 2013, pp. 68-75. https://doi.org/10.11648/j.ijepp.20130104.14

Nydick, R. L., Hill, R.P.,(1992), Using the Analytic Hierarchy Process to Structure the Supplier Selection Procedure, International Journal of Purchasing and Materials Management, https://doi.org/10.1111/j.1745-493X.1992.tb00561.x

Önüt S., Kara S. S., \& Ișik E. (2009). Long term supplier selection using a combined fuzzy M CDM approach: A case study for a telecommunication company. Expert Systems with Applications, $36(2$ PART 2), 3887-3895. https://doi.org/10.1016/j.eswa.2008.02.045

Rouyendegh B.D. (2014). Supplier Selection Using Integrated Fuzzy TOPSIS and MCGP, Procedia-Social and Behavioral Sciences 116, 3957-3970. https://doi.org/10.1016/j.sbspro.2014.01.874

Sarkis, J., \& Talluri, S. (2002). A Model for Strategic Supplier Selection. Journal of Supply Chain Management, 38(4), 18-28. https://doi.org/10.1111/j.1745-493X.2002.tb00117.x

Sindhu, M. S., Rashid, T., Kashif, A., \& Guirao, J. L. G. (2019). Multiple Criterion Decision Making Based on Probabilistic IntervalValued Hesitant Fuzzy Sets by Using LP Methodology. Discrete Dynamics in Nature and Society, 2019. https://doi.org/10.1155/2019/1527612

Soukup W.R., (1987), “Supplier selection strategies”, Journal of Purchasing and Materials Management, 23, 77 - 82.

Timmerman, E., 1986. An approach to vendor performance evaluation. Journal of Purchasing and Materials Management 22, $2-8$.

Thompson, K. N., (1990), Vendor Profile Analysis, Journal of Purchasing and Materials Management, https://doi.org/10.1111/j.1745-493X.1990.tb00494.x

Weber, C. A., Current, J. R., \& Benton, W. C. (1991). Vendor selection criterion and methods. European Journal of Operational Research, 50(1), 2-18. https://doi.org/10.1016/0377-2217(91)90033-R

Xian S. and Guo, H., Novel supplier grading approach based on interval probability hesitant fuzzy linguistic TOPSIS, 2020 https://doi.org/10.1016/j.engappai.2019.103299.

You X.Y., You J.X., Liu H.C., Zhen L. (2015). Group multi-criteria supplier selection using an extended VIKOR method with interval 2-tuple linguistic information. https://doi.org/10.1016/j.eswa.2014.10.004

Zadeh L.A. (1965). Fuzzy Sets. Information and Control, 8(3), 338-353. https://doi.org/10.1016/S0019-9958(65)90241-X 